\title{
Effects of leadership and adversity quotient On the employee commitment
}

\author{
Qamaruddin ${ }^{1}$, Adam Mukti, Margaretha ${ }^{2}$ \\ Sekolah Tinggi Ilmu Maritim “AMI" Jakarta ${ }^{1}$, Sekolah Tinggi Ilmu Maritim \\ "AMI" Jakarta ${ }^{2}$ \\ qomarudin.q@gmail.com ${ }^{1}$
}

\begin{abstract}
Research on employee commitment is important for it has a relationship with desired outcomes such as high performance, low turnover and absenteeism. The objective of this research is to study the effect of leadership and adversity quotient (AQ) on the employee commitment. The research approach is quantitative and the analysis technique is path analysis. The research was conducted at PT.YKK AP Indonesia located in Tangerang, Banten, using survey with the samples of 92 employees being selected simple randomly. The research findings show: (1) leadership has positively and significantly affected the employee commitment; (2) adversity quotient (AQ) has positively and significantly affected the employee commitment; (4) leadership has positively and significantly affected the adversity quotient. Based on these findings, it can be concluded that enhancing the employee commitment can be done through strengthening leadership and improving adversity quotient.
\end{abstract}

Keywords: adversity quotient, employee commitment, leadership

\section{Introduction}

Research on employee commitment is important for the following reasons: first, there is a link between commitment and attendance and turnover. Employees who are committed (engaged employees), 87 percent are less likely to leave the organization or in other words low turnover (Armstrong, 2010: 159); second, there is a positive relationship between employee commitment and desired outcomes such as high performance, low turnover and absenteeism (Luthans, 2011: 148); third, there is a negative relationship between employee commitment and absenteeism and turnover (Robbin and Judge, 2010: 111). Attendance and turn over are also categorized as physical withdrawal (Colquit, LePine and Wesson, 2013: 64-72).

The contextual problems that become the background of this research are as 
follows: First, leadership and employee commitment. The role of leaders in organizations is very important and central. Important because leaders are required to influence the behavior of their members. Central because he is the center of attention of his members. What the leader shows and displays will be perceived by the members and in turn will have an impact on their behavior. If in reality the attitude and behavior of leaders are perceived positively by the members, their positive attitudes and behavior will emerge. Vice versa, if the attitude and behavior of leaders are perceived negatively, then the attitudes and behavior of the members are negative too. This will be manifested in the form of their commitment to the organization. Luthans (2011: 148) shows that employee commitment is influenced by leadership style. The results of the research that has been done: Gao, Bai and Shi (2011) show that leadership influences employee commitment.

Second, adversity quotient and employee commitment. In Adversity Quotient @ Work (2003: 28), the concept of Adversity Quotient (AQ) was put forward by Paul Stoltz after conducting 20 years of research and studying around 1500 references from around the world. Adversity Quotient or Adversity Intelligence describes the pattern of processing responses to all forms and intensities of difficulties, from large tragedies to trivial disturbances. People who respond most effectively to adversity will succeed in work and life. Adversity quotient (AQ) is a person's endurance in facing difficulties and the ability to overcome them; while employee commitment is the attachment of employees to maintain their membership in the organization and a strong desire to contribute to the success of the organization. Langvardt in the Peak Learning website (www.peaklearning. com) stated that Adversity Quotient correlated positively with employee commitment.

Based on the background above, the problem of this research is how to increase employee commitment with the hypothesis that leadership (X1) and adversity quotient (X2) have a positive direct effect on employee commitment (Y).

\section{Research Design And Methodology}

The method used is a quantitative method with a causal technique using path analysis. The dependent variable here is employee commitment, whereas the independent variable is leadership and adversity quotient (AQ). Intervening variable is adversity quotient (AQ). The population was all employees who worked at PT. YKK AP Indonesia with a permanent status of 553 people. Furthermore, the sample frame is determined based on the criteria: (1) Grade / level $=$ S4-S5 / supervisor, (2) Work period $\geq 5$ years, and (3) Age $\leq 45$ years. Based on employee data, there was existing the number of sample framework 
with the above criteria was 120 people. The sampling technique was Simple Random and to get the sample size was by applying the Taro Yamane formula, obtained a sample of 92 people.

Data was collected using instruments in the form of questionnaires using a Likert scale with a scale range of 1 to 5 . Then the instrument was tested to test the validity and reliability test. After the results of the trial are then carried out the actual data research, descriptive and inferential analysis. The calculations use the MS-Excel and SPSS version 20.0.

\section{Findings And Conclusions}

Figure 1 below is an empirical model of the structural relationship between variables based on the results of path analysis calculation).

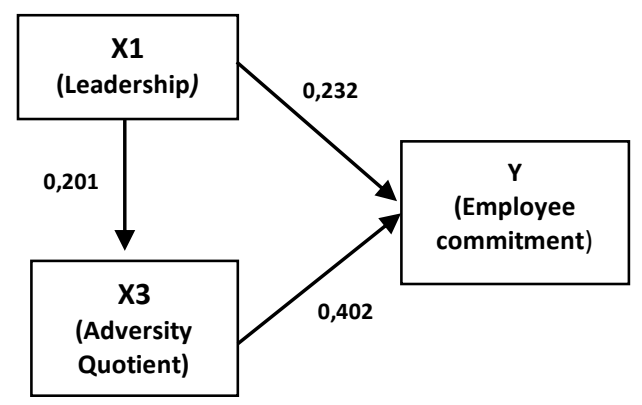

Fig. 1. Empirical model of structural correlation between variables

Based on the research findings, in Figure 1, it can be seen that there are 2 (two) significant of path coefficients at level $\alpha=0.05$ because they have t-count $>\mathrm{t}$ table, namely pY1 and pY2. The detailed explanation is described as follows:

\section{Leadership (X1) has a positive direct effect on adversity quotient (X2)}

The path diagram consists of 2(two) sub-structures that contains one exogenous variable $\mathrm{X} 1$ and an endogenous variable, namely $\mathrm{X} 2$. The structural equation for the path diagram is; $X 2=p 21 X 1+\varepsilon 1$. The results of SPSS v. 20.0 in sub-structure 1 , path coefficients X1 to X2 $(\mathrm{p} 21)=0.201$ and $\mathrm{t}$-count $=1.948$. The value of $\mathrm{t}$ table $=1.662$ at $\alpha=0.05$ and $\mathrm{p}$-value $(\mathrm{Sig})=0.055 / 2=0.025<0.05$. Since the value of $\mathrm{t}$-count $(1,948)>\mathrm{t}$ table $(1,662)$, then the path coefficient is significant. 
Simply put, leadership correlation with adversity quotient can be formulated, namely how leaders influence subordinates behavior so that subordinates are able to overcome difficulties at a high level.

Ronald Heifetz in Yukl (2010: 339) states that the leader's main role is to help followers face conflict and find productive ways to solve it. Leaders need to involve people in facing challenges, changing perspectives and learning new ways to work together effectively. One of the main function of leaders is to influence people to accept and understand an important problem rather than reject it. Implicitly there can be stated a causal relationship between leadership and adversity quotient.

The results of previous studies conducted by Ferrer (2009), states that there is a significant relationship between leadership and adversity quotient in control dimension.

The results of this study, after being tested statistically, show that path coefficients $\mathrm{p} 31=0.201$ and $\mathrm{t}$-count $=1.948$. Given $\mathrm{t}$-table $=1.662$ at the level of $\alpha=0.05$ and since the value of $t$-count is greater than $t$-table, the path coefficient is significant. This means that it can be concluded that leadership has a positive direct effect on adversity quotient (AQ). Thus the results of this study are in line with the theory and support the results of previous studies.

Based on the this finding, employee adversity quotient (AQ) can be improved by providing support and encouraging employees to do difficult tasks, delegating responsibilities and monitoring the process, helping employees to solve problem effectively.

\section{Leadership (X1) and adversity quotient (X2) have a direct positive effect on employee commitment (Y)}

The path diagram consists of a sub structure containing two exogenous variables $\mathrm{X} 1, \mathrm{X} 2$, and an endogenous variable, namely $\mathrm{Y}$. The structural equation for the path diagram is; $\mathrm{Y}=\mathrm{pY} 1 \mathrm{X} 1+\mathrm{pY} 2 \mathrm{X} 2+\varepsilon 2$. The results of processing the SPSS version 20.0 program in sub-structure 2 are obtained as follows:

1) Path coefficient pY1 $=0.203$ and t-count $=2,476$; $p$-value $(\operatorname{Sig})=0.016 /$ $2=0.008<0.05$. Since the value of $t$-count $(2,476)>t$-table $(1,662)$, the path coefficient is significant. This means that the leadership variable (X1) has a positive direct effect on employee commitment(Y). 
2) $\mathrm{pY} 2$ path coefficient $=0.402$ and t-count $=4.291 ; \mathrm{p}$-value $(\mathrm{Sig})=0.000 /$ $2=0,000<0.05$. Since the value of $t-\operatorname{count}(4.291)>t$-table $(1,662)$, the path coefficient is significant. This means that the adversity quotient (X2) has a direct positive effect on employee commitment (Y).

In simple terms, it can be stated that leadership is how to influence others whereas employee commitment is the willingness of employees to survive and do the best for the organization. Thus, conceptually, it is clear that the existence of strong leadership can affect one's commitment.

The essence of leadership, according to Yukl (2010: 198) is influence. The outcome of the influence is commitment, compliance and resistance. In terms of correlation, this means that leadership has a direct influence on commitment. Yukl (2010: 296-297) also emphasized the importance of the leader's responsibility in leading change, which is to influence his followers to commit to the change.

Still according to Yukl (2010: 31) leadership can be viewed from 5 (five) approaches: (1) traits approach, (2) behavioral approach (3), powerinfluence approach, (4) situational approach and (5) integrative approach. A brief description of the five approaches is outlined in the following paragraph.

The traits approach emphasizes the characteristics of leaders such as personality, motives, values and skills. Behavioral approach has in connection with the pattern of activities, responsibilities and functions in work including how to resolve conflicts, meet demand, see opportunities and overcome obstacles. The power-influence approach is related to the process of influencing between leaders and others. The assumption of this approach is unidirectional, namely the leader takes action and the followers react. The power here is not only affecting subordinates but also colleagues, superiors, and people outside the organization including customers and suppliers. The situational approach emphasizes the importance of contextual factors that influence the leadership process. The main situational variables include the characteristics of followers, the nature of the work performed in the unit, the type of organization and the state of the external environment. An integrative approach involves all the variables mentioned above, namely the nature, behavior, influencing process, situational variables and outcomes.

Based on the description of the five leadership approaches, it can be understood that the characteristics of the leader, his behavior, the process influencing and situational factors, will produce an outcome which in this context is the commitment of subordinates or people associated with it. 
In line with the description above, Colquitt, LePine and Wesson (2013: 483) state that transformational leadership has a strong positive influence on employee commitment. For example, employees led by transformational leadership tend to feel more optimistic and not easily frustrated while working, which of course makes them more easily, committed to work.

Another similar opinion was expressed by Luthans (2008: 147,430,453), namely that employee commitment is determined, among other things, by leadership style. The leadership style in this context, is authentic leadership. Authentic leadership comes from the theory of positive organizational behavior and transformational leadership.

Based on the opinions of Yukl, Colquitt, LePine and Wesson and Luthans, theoretically it has been shown that leadership has a positive effect on employee commitment.

The results of relevant research that show the effect of leadership on employee commitment are carried out by: (1) Gao, Bai and Shi (2011) who draw the conclusion that transformational leadership has a positive effect on organizational commitment, (2) Shastri, Mishra and Sinha (2010) states that there are two main factors namely charismatic leadership and job satisfaction that have the strongest effect on employee commitment.

The results of this study, after being tested statistically, show the path coefficients $\mathrm{pY} 1=0.203$ and $\mathrm{t}$-count $=2.450$. Given $\mathrm{t}$-table $=1.662$ and since the value of $\mathrm{t}$-count is greater than $\mathrm{t}$-table, the path coefficient is significant. This means that it can be concluded that leadership has a positive direct effect on employee commitment. Thus the results of this study are in accordance with the theory and support the results of previous studies.

The results of previous relevant research conducted by Langvardt showed that individual with higher adversity quotient had higher commitment. Overall, adversity quotient is positively correlated with employee commitment. Likewise research conducted by Peak Learning which shows that high adversity quotient (AQ) causes high retention, also increases engagement.

In this study, after being tested statistically, obtained path coefficient $\mathrm{pY} 3=$ 0.402 and $\mathrm{t}$-count $=4.291$, and from the $\mathrm{t}$-table obtained $\mathrm{t}$ table $=1.662$. Since the value of $t$-count is greater than t-table, the path coefficient is significant. These findings can be interpreted that adversity quotient has a positive direct effect on employee commitment. 
Based on the results of this study, it can be concluded that leadership emphasizing the importance of relationship, has a dominant influence on employee commitment, and adversity quotient showing the ability to perceive the situation positively and the willingness to accept responsibility without questioning the cause, has a major influence on employee commitment.

\section{Recommendations}

In an effort to increase the commitment of employees, the following recommendations are provided: (1) Leaders are appealed to play their role by day-to-day encouraging employees to carry out tasks according to the objectives or programs that have been set. At the same time, leaders also maintain good relationships with employees. Furthermore, in dealing with employee problems both personal and the number of internal problems in production, quality and quantity, leaders have the opportunity to increase the adversity quotient of employees. (2) The organization of PT. YKK AP Indonesia should pay more attention to the leadership of each leader because this has a great effect on improving soft-competency, adversity quotient and employee commitment. Therefore the leaders themselves should be monitored not only on the targets to be achieved, but also their behavior and efforts in achieving those targets. The leaders are also advised to be able to understand their employees personally, respect them, give assignments and encourage them in finding alternative solutions to difficult problems.

\section{References}

Armstrong, Michael.(2010). Essential Human Resource Management Practice. Kogan Page.

Avolio et.al.(2004).'Transformational and organizational commitment: mediating role of psychological empowerment and moderating role of structural distance" Journal of Organizational Behavior.pp. 951-968.

Colquitt, Jason A., Jeffery A.LePine dan Michael J.Wesson.(2011).Organizational Behavior. New York: McGraw-Hill.

Ferrer, Marissa B.(2009). Relationship of personal characteristics, leadership styles and job satisfaction to AQ, Dissertation (http: Ilwww.peaklearning.com/aqresearchers_research_completed.php) 
Gao, Fei Yi, Shanshan Bai dan Shi Kan.(2011). "The effect of transformational leadership on organizational commitment of family employees in Chinese family business", International Conference on Economics, Trade and Development. Singapore, IPEDR Vol.7.pp.218-224.

Luthans, Fred.(2011).Organizational Behavior. New York: McGraw-Hill.

Peak Learning, Inc., AQ Validation Studies, www.peaklearning.com

Shani, A.B et al.(2009).Behavior in Organization: An Experiental Approach. New York: McGraw Hill.

Shastri, R.K, K.Shashi Mishra and A.Sinha.(2010)."Charismatic Leadership and Organizational commitment: An Indian perspective", African Journal of Business and Management. Vol.4, no.10, 18 August. pp.1946-1953

Stoltz, Paul G. Adversity Quotient @ Work.(2003). translated by Alexander Sindoro. Batam: Interaksara.

Yukl, Gary. (2010).Leadership in Organizations. New Jersey: Pearson. 